\title{
ANALISIS FAKTOR PENYEBAB KEGAGALAN USAHA PENERIMA PROGRAM MAHASISWA WIRAUSAHA (PMW) DI UNIVERSITAS PENDIDIKAN GANESHA (UNDIKSHA TAHUN 2013
}

\author{
I Wayan Wartika \\ Jurusan Pendidikan Ekonomi, Fakultas Ekonomi dan Bisnis \\ Universitas Pendidikan Ganesha \\ Singaraja, Indonesia \\ e-mail: Wartika Wayan@rocketmail.com
}

\begin{abstract}
ABSTRAK
Penelitian ini bertujuan untuk mengetahui faktor-faktor yang mempengaruhi kegagalan usaha penerima PMW di Undiksha tahun 2013, dan faktor yang paling dominan mempengaruhi kegagalan usaha penerima program mahasiswa wirausaha di Undiksha tahun 2013. Penelitian ini dilaksanakan di Undiksha dengan jumlah responden sebanyak 30 orang. Data yang dikumpulkan dengan metode kuisioner, dianalisis dengan analisis faktor melalui Statistical Program Social Scence (SPSS) 16.0 for windows. Hasil penelitian menunjukkan bahwa terdapat delapan faktor yang mempengaruhi kegagalan usaha penerima program mahasiswa wirausaha di Undiksha tahun 2013, yaitu faktor kompeten dalam manajerial, faktor pengalaman, faktor keuangan, faktor perencanaan, faktor lokasi, faktor pengawasan, faktor sikap dan faktor peralihan/transisi. Faktor kompeten dalam manajerial, faktor pengalaman, dan faktor keuangan menjadi faktor paling dominan yang memiliki variance explained tertinggi yaitu masingmasing sebesar $28,793 \%, 21,459 \%$ dan $13,790 \%$, artinya total nilai varianced explained dari ketiga faktor keseluruhan mampu mempengaruhi kegagalan usaha penerima PMW di Undiksha tahun 2013 sebesar $64,042 \%$.
\end{abstract}

Kata Kunci: Program Mahasiswa Wirausaha (PMW)

\begin{abstract}
This study aims to determine the factors that influence the failure of PMW receiver's effort in Undiksha in year 2013, and the most dominant factor influencing student entrepreneurship program receiver's effort failure in Undiksha in year 2013. This research was conducted in Undiksha with 30 people as the respondents. Data were collected by questionnaire method, analyzed by factor analysis through Social Science Statistical Program (SPSS) 16.0 for Windows. The results showed that there were eight factors that influence the failure of student entrepreneurship program receiver's effort in Undiksha in year 2013, such as factors of competence in the managerial, factors of experience, factors of financial, factor of planning, factor of location, factors of surveillance, factors of attitude and factor of transition. Factors of competent in managerial, factors of experience, and factors of financial become the most dominant factor that has the highest explained variance respectively $28.793 \%, 21.459 \%$ and $13.790 \%$, which means that the total value of varianced explained from the whole three factors could affect PMW receiver's effort failure in Undiksha in year 2013 amounted to $64.042 \%$.
\end{abstract}

Keywords: Students Entrepreneurship Program (PMW)

\section{PENDAHULUAN \\ Undang-undang dasar Negara \\ Indonesia telah mengamanatkan tentang upaya mencerdaskan kehidupan bangsa. Hal ini menunjukkan bahwa setiap warga negara usia sekolah mulai dari tingkat dasar hingga perguruan tinggi harus mengenyam}

pendidikan. Sesungguhnya pendidikan tinggi mempunyai peran yang sangat strategis dalam menyiapkan sumberdaya manusia penggerak pembangunan bangsa. Sumber daya manusia yang unggul akan mendorong pertumbuhan bangsa baik dalam bidang 
ilmu pengetahuan, teknologi maupun sektor ekonomi. Untuk itulah Perguruan Tinggi (PT) perlu menyiapkan lulusan yang mampu menciptakan peluang tersebut.

Keterbatasan

peluang

terserapnya lulusan perguruan tinggi bekerja di sektor pemerintahan menyebabkan mereka beralih ke sektor swasta. Namun peluang bekerja di sektor swasta juga semakin terbatas. Dengan demikian satu-satunya peluang yang masih sangat besar adalah berwirausaha. Berwirausaha merupakan peluang yang menjamin bagi seorang sarjana untuk memiliki penghasilan sendiri dan membantu menciptakan lapangan pekerjaan bagi orang lain, namun jarang ditemukan seorang sarjana mengawali karirnya dengan berwirausaha.

Menurut Alma (2005:6) "dengan bekal pendidikan tinggi yang diperoleh di bangku kuliah dan idealisme yang terbentuk, lulusan perguruan tinggi diharapkan mampu mengembangkan diri menjadi seorang wirausahawan". Perguruan tinggi sebagai salah satu lembaga pendidikan seharusnya mengubah pola pikir mahasiswa yang bukan hanya pencari kerja, tetapi juga sebagai pencipta lapangan pekerjaan. Oleh sebab itu, perlu ditanamkan jiwa kewirausahaan kepada mahasiswa dengan memberikan pengetahuan kewirausahaan, baik dengan cara memasukan pendidikan kewirausahaan ke dalam kurikulum inti maupun dengan cara memberikan pelatihan-pelatihan kewirausahaan. Dalam rangka menumbuhkembangkan semangat jiwa kewirausahaan bagi mahasiswa, Direktorat Jenderal Pendidikan Tinggi telah meluncurkan suatu program yang disebut Program Mahasiswa Wirausaha (PMW) untuk dilaksanakan dan dikembangkan oleh perguruan tinggi. Program

Mahasiswa Wirausaha (PMW) yang diusung sejak tahun 2009 tersebut bertujuan untuk memberikan bekal pengetahuan, keterampilan dan sikap atau jiwa wirausaha (entrepreneurship) berbasis IImu Pengetahuan dan
Teknologi (IPTEK) kepada para mahasiswa agar dapat mengubah pola pikir (mindset) dari pencari kerja (jobseeker) menjadi pencipta lapangan pekerjaan (job creator) serta menjadi pengusaha yang tangguh dan sukses menghadapi persaingan global (DIKTI:2012). Program ini juga dimaksudkan untuk memfasilitasi para mahasiswa yang mempunyai minat dan bakat kewirausahaan untuk memulai berwirausaha dengan basis IImu Pengetahuan dan Teknologi (IPTEK) yang sedang dipelajarinya. Fasilitas yang diberikan meliputi pendidikan dan pelatihan kewirausahaan, magang, penyusunan rencana bisnis, dukungan pinjaman permodalan dan pendampingan usaha. Dalam pelaksanaan kegiatan Program Mahasiswa Wirausaha (PMW) ini, DIKTI menetapkan pedoman yang harus diukuti oleh pihak Perguruan Tinggi untuk memudahkan dalam mengevaluasi keberhasilan Perguruan Tinggi dalam menyelenggarakan program.

Universitas Pendidikan Ganesha (Undiksha) sebagai salah satu universitas yang juga melaksanakan Program Mahasiswa Wirausaha (PMW) tersebut sejak tahun 2010. Program tersebut mampu menarik minat mahasiswa untuk berwirausaha. Berdasarkan data yang diperoleh menunjukkan bahwa pada tahun 2010 jumlah mahasiswa yang terlibat dalam Program Mahasiswa Wirausaha sebanyak 100 orang yang terdiri dari 21 tim, Pada tahun 2011 jumlah mahasiswa yang terlibat dalam Program Mahasiswa Wirausaha sebanyak 116 orang yang terdiri dari 31 tim, dan pada tahun 2012 jumlah mahasiswa yang terlibat dalam Program Mahasiswa Wirausaha sebanyak 46 orang yang terdiri dari 16 tim, serta pada tahun 2013 jumlah mahasiswa yang terlibat dalam Program Mahasiswa Wirausaha sebanyak 86 orang yang terdiri dari 21 tim (Pokja: 2014).

Namun ketertarikan mahasiswa untuk mengikuti Program Mahasiswa Wirausaha (PMW) tersebut tidak semua 
diiringi dengan keberhasilan dalam menjalankan usahanya sampai monitoring berakhir. Tim yang berhasil dalam menjalankan usahanya sampai monitoring berakhir yaitu, pada tahun 2010 yang berhasil menjalankan usahanya sejumlah 5 tim $(23,80 \%)$ dari total 21 tim, pada tahun 2011 yang berhasil menjalankan usahanya sejumlah 16 tim $(51,61 \%)$ dari total 31 tim, dan pada tahun 2012 yang berhasil menjalankan usahanya sejumlah 5 tim $(31,25 \%)$ dari total 16 tim, serta pada tahun 2013 yang berhasil menjalankan usahanya sejumlah 12 tim $(57,14 \%)$ dari total $21 \mathrm{tim}$.

Program Mahasiswa Wirausaha (PMW), merupakan bagian dari strategi pendidikan di Perguruan Tinggi (PT) dimaksudkan untuk memfasilitasi mahasiswa yang mempunyai minat berwirausaha dan melalui usaha dengan basis ilmu pengetahuan, teknologi dan seni. Fasilitas yang diberikan meliputi pendidikan dan pelatihan kewirausahaan, magang, menyusun rencana bisnis, dukungan permodalan dan pendampingan usaha. Program ini diharapkan mampu mengubah pola pikir (mindset) dari pencari kerja (job seeker) menjadi pencipta lapangan pekerjaan (job creator) serta menjadi pengusaha yang tangguh dan sukses menghadapi persaingan global.

Universitas Pendidikan Ganesha (Undiksha) merupakan salah satu Perguruan Tinggi Negeri yang menyelenggarakan Program DIKTI tersebut. Undiksha mengembangkan Program Mahasiswa Wirausaha yang dikelola langsung oleh Kelompok Kerja (POKJA) Undiksha di bawah Koordinasi Bidang Kemahasiswaan. Program Mahasiswa Wirausaha (PMW) dalam pelaksanaannya mempunyai latar belakang dan tujuan.

Adapun latar belakang pelaksanaan Program Mahasiswa Wirausaha (PMW) yang ditetapkan oleh DIKTI dan Undiksha yaitu: 1) jumlah pengangguran terbuka berlatar belakang pendidikan tinggi cukup besar, hal ini dapat menimbulkan dampak negatif terhadap stabilitas sosial dan masyarakat; 2) rendahnya daya serap industri untuk menampung para lulusan Perguruan Tinggi (PT) karena tidak baanyak terjadi ekspensi kegiatan usaha; 3) menumbuhkembangkan jiwa entrepreneur para lulusan PT; 4) mendorong peran perguruan tinggi untuk mencetak para calon entrepreneur.

Tujuan program Mahasiswa Wirausaha (PMW) seperti yang telah dicantumkan dalam pedoman PMW yang ditetapkan oleh DIKTI yaitu : 1) menumbuhkembangkan wirausahawirausaha baru yang berpendidikan tinggi dan memiliki pola pikir pencipta lapangan kerja; 2) mendorong terbentuknya model pendidikan kewirausahaan di perguruan tinggi; 3) mendorong pertumbuhan dan perkembangan kelembagaan pengelola kewirausahaan mahasiswa di perguruan tinggi.

Tujuan Program Mahasiswa Wirausaha yang ditetapkan DIKTI tersebut di atas dikembangkan lagi oleh Undiksha menjadi beberapa bagian lagi yaitu : 1) menumbuhkan motivasi berwirausaha di kalangan mahasiswa; 2) membangun sikap mental wirausaha, yakni percaya diri, sadar akan jati dirinya, bermotivasi untuk meraih suatu cita-cita, pantang menyerah, mampu bekerja keras, kreatif, inovatif, berani mengambil resiko dengan perhitungan, berprilaku pemimpin dan memiliki visi kedepan, tanggap saran dan kritik, memiliki kemampuan empati, keterampilan sosial dan bermoral; 3) meningkatkan kecakapan dan keterampilan para mahasiswa khususnya sense of entrepreneur; 4) menumbuhkembangkan wirausahawirausaha baru yang berpendidikan tinggi; 5) menciptakan unit usaha baru yang berbasis ilmu pengetahuan, teknologi, dan seni; 6) membangun jejaring usaha antar pelaku usaha, khususnya antara wirausaha pemula dan pengusaha yang sudah mapan.

$$
\text { Menurut Zimmerer (dalam }
$$

Suryana, 2001), mengemukakan beberapa faktor-faktor yang 
menyebabkan wirausaha gagal dalam menjalankan usaha barunya yaitu : 1) tidak kompeten dalam manajerial. Tidak kompeten atau tidak memiliki kemampuan dan pengetahuan mengelola usaha merupakan faktor penyebab utama yang membuat perusahaan kurang berhasil; 2) kurang berpengalaman baik dalam kemampuan teknik, kemampuan memvisualisasikan usaha, kemampuan mengkoordinasikan, keterampilan mengelola sumber daya manusia, maupun kemampuan mengintegrasikan operasi perusahaan; 3) kurang dapat mengendalikan keuangan. Agar perusahaan dapat berhasil dengan baik faktor yang paling utama dalam keuangan adalah memelihara aliran kas. Mengatur pengeluaran dan penerimaan secara cermat. Kekeliruan dalam memelihara aliran kas akan menghambat operasional perusahaan dan mengakibatkan perusahaan tidak lancar; 4) gagal dalam perencanaan. Perencanaan merupakan titik awal dari suatu kegiatan, sekali gagal dalam perencanaan maka akan mengalami kesulitan dalam pelaksanaan. Kegagalan dalam menerapkan rencana biasanya karena rencana yang telah dibuat berdasarkan pengalaman orang lain atau sebuah idealis yang belum pernah diaplikasikan. Kegagalan ini terjadi karena tidak tahu sama sekali kondisi atau medan usaha yang digelutinya; 5) lokasi yang kurang memadai. Lokasi usaha yang strategis merupakan faktor yang menentukan keberhasilan usaha. Lokasi yang tidak strategis dapat mengakibatkan perusahaan sukar beroperasi karena kurang efisien. Tempat usaha dan lokasi sangat menentukan kelancaran bisnis yang digeluti. Salah memilih, membangun, atau membuka tempat usaha yang harapnnya dapat memperbesar usaha justru kandas karena kesalahan tersebut. Tempat usaha seharusnya diperiksa dulu kelayakannya seperti budaya, karakter, strata sosial, pendapatan, selera, kemanan masyarakat disekitarnya; 6) kurangnya pengawasan peralatan.
Pengawasan erat kaitannya dengan efisiensi dan efektivitas. Kurang pengawasan dapat mengakibatkan penggunaan alat tidak efisien dan tidak efektif. Kemampuan dalam pengadaan, pemeliharaan, pengawasan bahan baku dan peralatan yang dimiliki sangatlah penting. Karena apabila tidak memiliki kemapuan dalam bidang ini akan membuat biaya operasioanal semakin tinggi dan kerugian akan terjadi; 7) sikap yang kurang sungguh-sungguh dalam berusaha. Sikap yang setengahsetengah terhadap usaha akan mengakibatkan usaha yang dilakukan menjadi labil dan gagal. Dengan sikap setengah hati, kemungkinan gagal akan besar. Keberhasilan seorang wirausaha bisa diperoleh apabila mampu percaya diri, dan selalu optimis dalam menjalankan usahanya; 8) ketidakmampuan dalam melakukan peralihan/transisi kewirausahaan. Wirausaha yang kurang siap menghadapi dan melakukan perubahan, maka ia tidak ada jaminan untuk menjadi wirausaha yang berhasil. Keberhasilan dalam berwirausaha hanya bisa diperoleh apabila berani mengadakan perubahan dan mampu membuat peralihan setiap waktu.

$$
\text { Selain faktor-faktor yang }
$$

membuat kegagalan wirausahawan, Zimmerer (dalam Suryana, 2001) mengemukakan beberapa potensi yang membuat seseorang mundur dari kewirausahaan yaitu : 1) pendapatan yang tidak menentu baik pada tahap awal maupun tahap pertumbuhan, dalam bisnis tidak ada jaminan untuk terus memperoleh pendapatan yang berkesinambungan. Dalam kewirausahaan, sewaktu-waktu dapat mengalami kerugian dan keuntungan. Tingkat ketidakpastian dalam bisnis berpotensi mundurnya seseorang dari kewirausahaan; 2) kerugian akibat hilangnya modal investasi tingkat kegagalan bagi usaha baru sangatlah tinggi. Kegagalan investasi dapat mengakibatkan seseorang mundur dari dunia kewirausahaan. Padahal, bagi wirausahawan, kegagalan sebaiknya dijadikan pelajaran berharga; 3) 
berwirausaha memerlukan kerja keras dan waktu yang lama wirausahawan biasanya bekerja sendiri dari mulai pembelian, pengolahan, penjualan, dan pembukuan. Apabila tidak dibarengi dengan kesabaran dan ketabahan dalam menggeluti berbagai masalah dan tantangan dapat berpeluang mundurnya seseorang dari kewirausahaan. Bagi wirausahawan yang berhasil pada umumnya menjadikan tantangan sebagai peluang yang harus dihadapi dan ditekuni; 4) kualitas kehidupan yang tetap rendah meskipun usahanya mantap kualitas kehidupan yang tidak segera meningkat dalam usaha, akan mengakibatkan seseorang menjadi putus asa dan mungkin mundur dari kewirausahaan. Wirausahawan sejati tentunya tidak akan mudah pasrah, justru keadaan yang dihadapi mendorongnya untuk terus mengadakan perbaikan-perbaikan dan memacu untuk maju terus pantang mundur.

\section{METODE}

Pengumpulan data dilakukan dengan metode kuesioner atau angket. Kuesioner dalam penelitian ini disebarkan kepada 30 responden yang merupakan Populasi seluruh mahasiswa yang mengalami kegagalan dalam menjalankan usaha Program Mahasiswa Wirausaha (PMW) di Undiksha tahun 2013. Menurut Arikunto (2005), apabila populasi kurang dari 100 orang, maka sebaiknya semua dijadikan sebagai sasaran penelitian. Oleh karena itu, penelitian ini merupakan penelitian populasi atau penelitian sampel jenuh yang artinya semua populasi dijadikan sebagai sasaran penelitian. Sumber data yang digunakan dalam penelitian ini adalah data primer, yaitu data yang diperoleh secara langsung terkait dengan faktorfaktor yang mempengaruhi kegagalan usaha penerima PMW di Undiksha tahun 2013 seperti kuisioner dan data sekunder, yaitu data yang diperoleh dari sumber-sumber yang dianggap perlu yang ada hubungannya dengan penelitian seperti nama mahasiswa dan jumlah usaha penerima PMW gagal yang diperoleh dari ketua Pokja Undiksha. Analisis data yang digunakan adalah analisis faktor. Pengujian hipotesis dilakukan dengan menggunakan Statistical Program Social Scence (SPSS) 16.0 for windows dengan menggunakan factor analysis.

\section{HASIL DAN PEMBAHASAN Hasil}

Data yang berhasil dikumpulkan dari kuisioner yang disebarkan dan setelah diolah dengan SPSS 16.0 for windows menunjukkan faktor-faktor yang mempengaruhi kegagalan usaha penerima PMW di Undiksha tahun 2013 dapat dijelaskan oleh nilai persentase dari masing-masing faktor. Nilai Total Variance Explained digunakan untuk mengetahui persentase dari kedelapan faktor yang dianalisis. Hasil analisis faktor melalui SPSS menunjukkan persentase dari masing-masing faktor dapat dilihat pada Tabel 1 berikut.

Tabel 1. Total Variance Explained

\begin{tabular}{|c|c|c|c|c|c|c|}
\hline \multirow[b]{2}{*}{ Component } & \multicolumn{3}{|c|}{ Initial Eigenvalues } & \multicolumn{3}{|c|}{ Extraction Sums of Squared Loadings } \\
\hline & Total & $\begin{array}{c}\text { \% of } \\
\text { Variance }\end{array}$ & $\begin{array}{c}\text { Cumulative } \\
\%\end{array}$ & Total & $\begin{array}{c}\text { \% of } \\
\text { Variance }\end{array}$ & Cumulative \% \\
\hline $\begin{array}{l}\text { Kompeten dalam } \\
\text { Manajerial }\end{array}$ & 2.303 & 28.793 & 28.793 & 2.303 & 28.793 & 28.793 \\
\hline Pengalaman & 1.717 & 21.459 & 50.252 & 1.717 & 21.459 & 50.252 \\
\hline Keuangan & 1.103 & 13.790 & 64.042 & 1.103 & 13.790 & 64.042 \\
\hline Perencanaan & .866 & 10.824 & 74.867 & & & \\
\hline Lokasi & .724 & 9.049 & 83.915 & & & \\
\hline Pengawasan & .523 & 6.534 & 90.450 & & & \\
\hline Sikap & .416 & 5.206 & 95.655 & & & \\
\hline Peralihan/Transisi & .348 & 4.345 & 100.000 & & & \\
\hline
\end{tabular}


Berdasarkan tabel 1 diatas, menunjukkan bahwa persentase dari faktor kompeten dalam manajerial memiliki eigenvalue sebesar 2,303 dengan nilai varian sebesar $28,793 \%$, faktor pengalaman memiliki eigenvalue sebesar 1,717 dengan nilai varian sebesar $21,459 \%$, faktor keuangan memiliki eigenvalue sebesar 1,103 dengan nilai varian sebesar $13,790 \%$. Sedangkan faktor perencanaan memiliki eigenvalue sebesar 0,866 dengan nilai varian $10,824 \%$, faktor lokasi memiliki eigenvalue sebesar 0,724 dengan nilai varian $9,049 \%$, faktor pengawasan memiliki eigenvalue sebesar sebesar 0,523 dengan nilai varian $6,534 \%$, faktor sikap memiliki eigenvalue sebesar 0,416 dengan nilai varian $5,206 \%$, dan faktor peralihan/transisi memiliki eigenvalue sebesar 0,348 dengan nilai varian $4,345 \%$. Jadi, kedelapan faktor-faktor tersebut mempengaruhi kegagalan usaha penerima PMW di Undiksha tahun 2013. Untuk menjelaskan kegagalan usaha penerima PMW di Undiksha tahun 2013, dapat dilakukan melalui ekstraksi faktor. Ekstraksi faktor dapat dijelaskan oleh total persentase dari masing-masing faktor utama. Faktorfaktor utama tersebut adalah faktor kompeten dalam manajerial, faktor pengalaman, dan faktor keuangan yang memiliki nilai parameter eigenvalue $>1$. Untuk mengetahui distribusi dimensidimensi yang belum dirotasi ke dalam faktor yang telah terbentuk maka dapat dilihat pada output SPSS 16.0 (Rotated Component Matrix). Untuk menjelaskan career plateau (kemandegan karir) guru pada SMPN 1 Denpasar, dapat dilakukan melalui ekstraksi faktor. Ekstraksi faktor dijelaskan oleh total persentase dari masing-masing faktor utama. Faktor-faktor utama tersebut adalah faktor usia, faktor lama bekerja, dan faktor tingkat pendidikan yang memiliki nilai parameter eigenvalue $>1$. Untuk mengetahui distribusi dimensi yang belum dirotasi ke dalam faktor yang telah terbentuk maka dapat dilihat pada output SPSS 16.0 (Rotated Component Matrix). Faktor yang mampu mempengaruhi kegagalan usaha penerima PMW di Undiksha tahun 2013, dapat dilihat pada Tabel 2 berikut.

Tabel 2 Faktor yang mempengaruhi kegagalan usaha penerima PMW di Undiksha Tahun 2013

\begin{tabular}{lrrr}
\hline \multicolumn{1}{c}{ Faktor } & Eigenvalue & Varianced Explained $(\%)$ & Factor Loading \\
\hline Kompeten dalam & 2.303 & 28.793 & .580 \\
Manajerial & 1.717 & 21.459 & .508 \\
Pengalaman & 1.103 & 13.790 & .814 \\
Keuangan & .866 & 10.824 & .532 \\
Perencanaan & .724 & 9.049 & .695 \\
Lokasi & .523 & 6.534 & .772 \\
Pengawasan & .416 & 5.206 & .695 \\
Sikap & .348 & 4.345 & .825 \\
Peralihan/Transisi & & & \\
\hline
\end{tabular}

Dilihat dari Tabel 2 di atas, dapat dijelaskan bahwa faktor yang memiliki eigenvalue $>1$ adalah kompeten dalam manajerial, pengalaman, dan keuangan, total nilai varianced explained dari ketiga faktor keseluruhan mampu menjelaskan sebesar 64,042\%, dengan demikian $64,042 \%$ dari seluruh faktor yang ada, dapat dijelaskan oleh ketiga faktor yang terbentuk. Kompeten dalam manajerial memiliki varianced explained $28,793 \%$, artinya bahwa Kompeten dalam manajerial mampu mempengaruhi kegagalan usaha penerima PMW sebesar $28,793 \%$. Pengalaman memiliki varianced explained $21,459 \%$, artinya bahwa Pengalaman mampu mempengaruhi kegagalan usaha penerima PMW sebesar 21,459\%. Keuangan memiliki varianced explained $13,790 \%$, artinya bahwa Keuangan 
mampu mempengaruhi kegagalan usaha penerima PMW sebesar $13,790 \%$.

Menentukan nama faktor yang telah terbentuk untuk masing-masing faktor bersifat subjektif, kadangkala faktor yang memiliki nilai faktor loading tertinggi digunakan untuk memberi nama faktor. Untuk melihat nilai faktor loading dapat dilihat pada Tabel 3 berikut.

Tabel 3 Rotated Component Matrix

\begin{tabular}{lrrr}
\hline & \multicolumn{3}{c}{ Component } \\
\cline { 2 - 4 } & 1 & 2 & 3 \\
Kompeten dalam Manajerial & .580 & .215 & -.698 \\
Pengalaman & -.558 & .508 & .425 \\
Keuangan & -.119 & .814 & -.040 \\
Perencanaan & -.407 & .254 & .532 \\
Lokasi & -.180 & .695 & -.091 \\
Pengawasan & .230 & .124 & .772 \\
Sikap & .698 & .421 & -.173 \\
Peralihan/Transisi & .825 & -.051 & .049 \\
\hline
\end{tabular}

Berdasarkan Tabel 3 di atas, dapat dikelompokkan menjadi 3 (tiga) faktor. Faktor 1 (satu) terbentuk dari faktor kompeten dalam manajerial (X1) dengan faktor loading sebesar 0,580, faktor sikap (X7) dengan faktor loading sebesar 0,698, dan faktor peralihan/transisi (X8) dengan faktor loading sebesar 0,825. Faktor 2 (dua) terbentuk dari faktor pengalaman (X2) dengan faktor loading sebesar 0,508 dan faktor keuangan (X3) dengan faktor loading sebesar 0,814 dan faktor lokasi (X5) dengan factor loading sebesar 0,695 . Faktor 3 (tiga) terbentuk dari faktor perencanaan (X4) dengan faktor loading sebesar 0,532 dan pengawasan (X6) dengan faktor loading sebesar 0,772 .

Kemudian untuk menentukan dimensi atau faktor yang mempengaruhi kegagalan usaha penerima Program Mahasiswa Wirausaha di Undiksha Tahun 2013 paling dominan digunakan parameter koefisien varimax atau mendekati -1 . Nilai yang mendekati 1 diawali oleh nilai 0,5 sedangkan nilai yang mendekati -1 diawali oleh -0,5. Secara lebih rinci hasil ringkasan rotasi dari matriks faktor memuat nilai varimax rotation, dapat dilihat pada Tabel 4 berikut ini .

Tabel 4. Matriks Rotasi Hasil Analisis Faktor

\begin{tabular}{lccc}
\hline Dimensi atau faktor & \multicolumn{3}{c}{ Varimax Rotation (\%) } \\
kegagalan usaha penerima \\
\cline { 2 - 4 } $\begin{array}{c}\text { PMW di Undiksha } \\
\text { Tahun 2013 }\end{array}$ & $(1)$ & $(2)$ & $(3)$ \\
\hline Kompeten dalam Manajerial & 28,793 & 21,459 & - \\
Pengalaman & - & 13,790 & - \\
Keuangan & - & & - \\
\hline
\end{tabular}




\begin{abstract}
Berdasarkan tabel 4, maka faktor yang paling dominan mempengaruhi kegagalan usaha penerima PMW di Undiksha tahun 2013 adalah faktor kompeten dalam manajerial dengan nilai varimax rotation $28,793 \%$. Artinya kejelasan dari dimensi atau faktor kegagalan usaha penerima PMW adalah kompeten dalam manajerial yang paling mendominasi sebesar $28,793 \%$, faktor pengalaman dengan nilai varimax rotation $21,459 \%$ dan faktor keuangan dengan nilai varimax rotation $13,790 \%$.
\end{abstract}

\section{Pembahasan}

Kegagalan usaha penerima Program Mahasiswa Wirausaha (PMW) di Undiksha Tahun 2013 dipengaruhi oleh faktor kompeten dalam manajerial, pengalaman, keuangan, perencanaan, lokasi, pengawasan, sikap, dan peralihan/transisi. Hal ini sesuai dengan teori yang dinyatakan oleh Zimmerer yang dikutip oleh Suryana, bahwa faktor yang mempengaruhi kegagalan seorang wirausaha adalah tidak kompeten dalam manajerial, kurang berpengalaman, kurang dapat mengendalikan keuangan, gagal dalam perencanaan, lokasi kurang memadai, kurangnya pengawasan peralatan, sikap yang kurang sungguh-sungguh, dan ketidakmampuan melakukan peralihan/transisi. Dengan demikian untuk menjelaskan yang mempengaruhi kegagalan usaha penerima PMW di Undiksha tahun 2013, dapat dilihat dari faktor-faktor yang memiliki eigenvalue > 1 yaitu, faktor kompeten dalam manajerial, pengalaman dan keuangan.

$$
\text { Faktor kompeten dalam }
$$

manajerial, pengalaman dan keuangan merupakan faktor yang paling dominan mempengaruhi kegagalan usaha penerima PMW di Undiksha tahun 2013. Faktor ini paling dominan dibandingkan faktor-faktor yang lain disebabkan karena kompeten dalam manajerial tidak hanya mencakup tentang mengatur usaha saja, namun dalam kegiatan menjalankan usaha dibutuhkan memiliki kemampuan dan pengetahuan mengelola sumberdaya manusia yang ada untuk mencapai keberhasilan suatu usaha. Sehingga ini merupakan faktor penyebab utama yang membuat perusahaan kurang berhasil. Banyaknya mahasiswa yang gagal dalam menjalankan usaha PMW di Undiksha tahun 2013, karena tidak memiliki keterampilan memimpin dan pembagian kerja dalam usaha yang masih dihadapi oleh mahasiswa penerima PMW di Undiksha tahun 2013. Ketika salah satu dari anggota yang mendapatkan tugas menjaga usahanya pada saat itu terbentur dengan perkuliahan, namun disaat itu pula usahanya ditutup karena tidak ada anggota yang lain untuk mengganti temannya yang sedang mengikuti perkuliahan untuk menjaga usahanya. Hasil penelitian ini sejalan dengan teori Suryana (2001), menjadi wirausaha yang berhasil diperlukan memiliki keterampilan, kemampuan atau kompetensi.

Faktor pengalaman merupakan dasar untuk menjalankan sebuah usaha dimana kesuksesan suatu kegiatan usaha harus dilandasi dengan pengalaman yang memadai. Kebanyakan mahasiswa yang gagal dalam menjalankan usaha PMW di Undiksha tahun 2013, karena pengalaman yang masih kurang. Terlebih lagi dalam proses persiapan menjalankan usaha PMW seharusnya dilakukan kegiatan magang bagi penerima PMW sebelum terjun menjalankan usahanya sendiri, namun kegiatan magang tersebut belum terealisasi. Sehingga pemahaman tentang menjalankan usahanya masih kurang. Hasil penelitian ini sejalan dengan teori Suryana ( 2001 ) yang dikutip dari A. Kuriloff, John M. Memphil, Jr dan Douglas Cloud, untuk mencapai keberhasilan suatu usaha tidak cukup dengan memiliki keterampilan dan kemampuan saja, namun dibutuhkan memiliki pengalaman yang seimbang.

Begitu pula dengan faktor keuangan merukapan modal dasar yang digunakan dalam menjalankan sebuah usaha. Faktor ini dominan 
dibandingkan faktor-faktor yang lain disebabkan karena kurang dapat mengendalikan keuangan terutama pada pemeliharaan aliran kas. Terutama pada saat mengatur pengeluaran dan penerimaan yang kurang cermat, misalnya dalam ;proses penjualannya pendapatan yang diperoleh tidak dilakukan pencatatan, sehingga menyebabkan kekeliruan. Kekeliruan dalam memelihara aliran kas akan menghambat operasional perusahaan sehingga mengakibatkan perusahaan tidak berjalan lancar. Dengan demikian mereka mengalami keterbatasan dan kesulitan untuk melakukan proses pembuatan pembukuan atau laporan laba/rugi yang seharusnya dibuat untuk mengetahui perkembangan dari perusahaan yang dimilikinya. Dengan demikian keterbatasan kemampuan dalam pemeliharaan aliran kas tersebut merupakan kendala yang dihadapi mahasiswa dalam menjalankan usaha PMW di Undiksha tahun 2013. Hasil penelitian ini sejalan dengan teori Basrowi ( 2014 ), Setiap pemilik bisnis harus mengendalikan catatan dan laporan keuangan untuk mengetaui kondisi keuangan bisnisnya. Pengusaha dalam membuat catatan-catatan hanya dipergunakan untuk keperluan pajak dan tidak dimanfaatkan sebagai alat pengendali yang vital, sehingga perusahaan sering mengalami kegagalan. Seorang wirausahawan paling tidak harus mempunyai pemahaman dasar mengenai akuntansi dan keuangan, sehingga pengusaha bisa mengenal apa yang terjadi dalam bisnisnya.

\section{SIMPULAN DAN SARAN Simpulan}

Berdasarkan hasil analisis data dan pembahasan, maka dapat ditarik simpulan yaitu faktor yang mempengaruhi kegagalan usaha penerima Program Mahasiswa Wirausaha (PMW) di Undiksha tahun 2013 adalah faktor kompetensi dalam manajerial dengan nilai varian sebesar $28,793 \%$, faktor pengalaman dengan nilai varian sebesar $21,459 \%$, faktor keuangan dengan nilai varian sebesar $13,790 \%$, faktor perencanaan dengan nilai varian $10,824 \%$, faktor lokasi dengan nilai varian 9,049\%, faktor pengawasan dengan nilai varian $6,534 \%$, faktor sikap dengan nilai varian $5,206 \%$, dan faktor peralihan/transisi dengan nilai varian $4,345 \%$. Sedangkan yang paling dominan mempengaruhi kegagalan usaha penerima Program Mahasiswa Wirausaha (PMW) di Undiksha tahun 2013 adalah faktor kompeten dalam manajerial dengan nilai varimax rotation sebesar $28,793 \%$, faktor pengalaman dengan nilai varimax rotation sebesar $21,459 \%$ dan faktor keuangan dengan nilai varimax rotation sebesar $13,790 \%$.

\section{Saran}

Berdasarkan simpulan yang diperoleh dari hasil penelitian ini, maka dapat dikemukakan saran-saran yaitu Bagi mahasiswa penerima Program Mahasiswa Wirausaha yaitu: 1) agar dapat memotivasi diri dengan membuat usaha yang baru lebih memperhatikan cara mengatur suatu usaha atau manajerial dalam perusahaan dan mengelola sumberdaya manusia dengan baik. Selain itu, diperlukan kemampuan dalam pengelolaan keuangan baik dari segi penerimaan maupun pengeluaran kas; 2) Bagi mahasiswa yang masih menjalankan usaha PMW diharapkan tidak mengalami kegagalan dalam usahanya, agar lebih memperhatikan dalam hal a) kompeten dalam manajerial, b) pengalaman, dan c) mengatur keuangan, sehingga dapat meminimalisasi jumlah mahasiswa yang mengalami kegagalan dalam menjalankan usahanya. Bagi Universitas Pendidikan Ganesha yaitu : 1) Lembaga Universitas Pendidikan Ganesha agar terus memotivasi dan melakukan evaluasi tentang pelaksanaan Program Mahasiswa Wirausaha (PMW) yang mengalami kegagalan dalam menjalankan usahanya, serta memberikan pengetahuan tentang kewirausahaan 
baik dengan memberikan pelatihan melalui kegiatan magang maupun memasukan mata kuliah kewirausahaan disetiap jurusan yang ada di Undiksha. Sehingga nantinya mahasiswa akan lebih mudah memahami tentang wirausaha dan bersemangat untuk terjun ke dunia usaha; 2) Lembaga Universitas Pendidikan Ganesha agar lebih memperketat dalam melakukan penyeleksian bagi calon penerima usaha PMW, terutama lebih memperhatikan, 1) kompeten dalam manajerial yang dimiliki mahasiswa, 2) pengalaman yang dimiliki mahasiswa, dan 3) pengaturan keuangan atau skil yang dimiliki mahasiswa dalam mengatur keuangan.

Bagi peneliti lain yang berminat untuk mendalami bidang manajemen sumber daya manusia terkait dengan kewirausahaan diharapkan melakukan penelitian lebih lanjut dengan beberapa Universitas. Hal ini berguna untuk membandingkan penyebab kegagalan yang terjadi di Universitas satu dengan yang lainnya.

\section{DAFTAR PUSTAKA}

Arikunto, Suharsimi. 2005. Prosedur Penelitian Edisi Kedua Belas. Jakarta: Rineka Cipta.

Basrowi. 2014. Kewirausahaan Untuk Perguruan Tinggi. Bogor: Ghalia Indonesia

Buchari Alma. 2005. Kewirausahaan untuk Mahasiswa dan Umum. Cetakan kedelapan (Edisi Revisi). Bandung: Alfabeta.

Buchari Alma. 2006. Kewirausahaan untuk Mahasiswa dan Umum. Bandung: Alfabeta.

2011. Kewirausahaan untuk Mahasiswa dan Umum. Bandung: Alfabeta.

2013. Kewirausahaan untuk Mahasiswa dan Umum. Cetakan ke 18. Bandung: Alfabeta.

\author{
Dikti. 2012. Pedoman Program \\ Mahasiswa Wirausaha (PMW). \\ Tersedia pada \\ http://www.dikti.go.id . Download \\ tanggal 25 september 2014.
}

Ghozali, Imam. 2006. Aplikasi Analisis Multivariate Dengan Program SPSS. Cetakan IV. Semarang: Badan Penerbit Universitas Diponegoro.

Heidjrachman Ranupandoyo. 1987. Teori dan konsep manajeman. Yogyakarta: BPFE - UGM.

Kasmir. 2006. Kewirausahaan. Edisi 12. Jakarta: PT Raja Grafindo Persada. 2013. Kewirausahaan. Cetakan kedelapan (Edisi Revisi). Jakarta: PT Raja Grafindo Persada.

Machfoedz Mas'ud dan Mahmud Machfoedz. 2004. Kewirausahaan Suatu Pendekatan Kontemporer. Yogyakarta: Unit Penerbit dan Percetakan Akademi Manajemen Perusahaan YKPN.

Pedoman Penulisan Skripsi dan Tugas Akhir Program Sarjana dan Diploma 3 Universitas Pendidikan Ganesha Tahun 2013.

Ridwan, dkk. 2011. Cara Mudah Belajar SPSS 17.0 Dan Aplikasi Statistik Penelitian. Cetakan ke 2. Bandung: Alfabeta

Sanusi Anwar. 2003. Metodologi Penelitian Praktis: Untuk IImu Sosial dan Ekonomi. Malang: Buntara Media.

Sativana, I Putu Desta. 2014. Tingkat Keberhasilan Program Mahasiswa Wirausaha (PMW) di Undiksha di Tinjau dari Aspek Unit Bisnis Tahun 2012. Skripsi Jurusan Pendidikan Ekonomi Universitas Pendidikan Ganesha. 
Soesarsono, Wijandi. 1988. Pengantar Kewirausahaan. Bandung: Sinar Baru.

Siregar, Syofian. 2011. Statistik Deskriptif Untuk Penelitian. Jakarta: PT. Raja Grafindo.

Sugiyono. 2009. Metode Penelitian Kuantitatif Kualitatif dan $R \& D$. Bandung: Alfabeta.

Suryana. 2001. Kewirausahaan. Edisi Pertama. Jakarta: Salemba Empat.

Suryana Yuyus dan Kartib Bayu. 2011. Kewirausahaan: Pendekatan
Karakteristik Wirausaha Sukses. Edisi Pertama. Jakarta: Kencana Prenada Media Group.

Totok S, Wiryasaputra. 2004. Entrepreneur: Anda Merdeka jadi bos. Jakarta: Tridaharma Manunggal.

Wiryani, Ni Wayan. 2013. Evaluasi Pelaksanaan Program Mahasiswa Wirausaha Di Universitas Pendidikan Ganesha Tahun 2012. Skripsi Jurusan Pendidikan Ekonomi Universitas Pendidikan Ganesha. 